\title{
Colonization and Massacres: Virginia Tech and Jamestown
}

\author{
Roxanne Dunbar-Ortiz
}

In April 2007, all the news seemed to be coming from Virginia and was about mass murder, occurring yesterday (400 years ago in Jamestown) and today (April 16, 2007). I haven't heard any commentary on the analogy of these bookends of colonialism in the press. Maybe it's that I'm writing the first chapter of a history of the United States and have genocide on my mind.

The Virginia Tech killings were heralded as the worst "mass killing," "worst massacre," in U.S. history. Descendants of massacred ancestors-indigenous peoples, African Americans, Mexicanos, Chinese-took exception to that designation. But, I know what those headlines meant; they meant the largest number of innocents killed by one armed civilian, although even that's probably not accurate either, so they really mean with guns and in the last halfcentury or so, maybe beginning in 1958 with nineteen-year-old Charles Starkweather and his even younger girlfriend Caril Fugate who killed eleven in Nebraska and Wyoming. Then, in 1966, there was Charles Whitman up on top of the University of Texas tower, sniping and killing 13, wounding 31 others before being shot by police. Twenty years later, the post office killings began, in the quiet town of Edmond, Oklahoma, a few miles from where I grew up, giving rise to a new term, "going postal." Other workplace killings followed, with around 50 deaths up to now. More recently, school killings, or back to school killings counting Whitman in 1966, have prevailed, some 22 incidents since 1989 in the United States (a significant number in other countries as well).

Having lived through all of them, I have been interested in each one, ever since Starkweather, who was my age at the time. Each mass killing is followed by an orgiastic chorus of proclamations of a sea of normality punctured by a sole evildoer. Perhaps the incidents play a role in the society somewhat as Dostoevsky had his character, the "idiot," play as the member of the family who is weird or evil so that the rest of the family can be perceived or perceive themselves as "normal." With all the anger and tension we experience and observe daily, it's a wonder mass killings don't happen more often, but maybe the mass killer speaks for many and is a preventative.

The Dostoevskian "idiot" is a universal archetype under the patriarchal western family and the triad of family, church, and state. But, there's more to it than that in the United States. This can be seen from how we react. Some say we react so massively because it's the 24-7 television media and internet that causes us to dwell on such events. But, I recall the Starkweather crime spree from my youth in rural Oklahoma with no television at all and only local papers, and it didn't even happen in Oklahoma.

I think we have to go back to that yesterday in another part of Virginia, Jamestown, the site of the British queen's visit in April to celebrate the first permanent English colony in the western hemisphere; Vice-President Dick Cheney, in his Jamestown speech commemorating the 400 year anniversary called the birthplace of the United States. Indeed it is, a bloody birth at that.

When Cho went on his killing spree, there was a great deal of news about the 400 year commemoration, especially in Virginia. Was Cho curious enough to do an internet search about Jamestown? (Maybe the FBI knows from studying Cho's hard drive.) Or maybe Cho just looked at a book, or had taken a history course. Perhaps he saw some pictures of drawings of the Powhatan Indians who were killed by Captain John Smith and his soldiers to take their corn. Perhaps Cho saw a reflection of his own features in those Powhatan faces, and was reminded of what had happened to his own people, the multiple massacres of Korean civilians in the 1950s U.S. invasion and occupation, 
the occupation continuing today. Or maybe it was Iraq.

In March, I had written a short essay, really a rant, that made the rounds on the internet, called "Hating the Rich." Although many comrade class warriors appreciated it, a few people warned that hatred leads to violence. I don't think that's true. In U.S. society we are not allowed to hate anyone or anything not designated by the State as the enemy. We are jumped on and accused of "playing the class card" or "playing the race card." I doubt that Cho was filled with hatred of any sort other than self-loathing. He did express scorn for "rich kids" in his videotaped suicide message, but the emotion was likely jealousy, or resentment, or maybe even love gone wrong, betrayal of that "American dream," he and his sister beneficiaries of their parents' near slave labor to pay for their elite educations.

And which is worse, Cho's destiny or that of his Princeton graduated sister working for the U.S. State Department's management of the Iraq war? 